\title{
Good Documentation Practice (Gap): Coordinate Regulatory Requirements in Pharmaceutical Manufacturing Industry
}

\author{
Joymalya Bhattacharya, M.Pharm (Pharmaceutics), Mba (Hrm), \\ M.Phil (Management) \\ Senior Chemist, Albert David Limited.5/11,D.Gupta Lane, Kolkata-700 050, India
}

\begin{abstract}
Basic Rules In Any Good Manufacturing Practice (Gmp) Regulations Specify That The Pharmaceutical Manufacturer Must Maintain Proper Documentation And Records. Documentation Helps To Build Up A Detailed Picture Of What A Manufacturing Function Has Done In The Past And What It Is Doing Now And, Thus, It Provides A Basis For Planning What It Is Going To Do In The Future. Because Of The Complexities Of Record Keeping In The Pharmaceutical Industry, There Are Inherent Challenges That Companies Face In Regard To Gdp. In A Gmp Environment Documentation Needs To Meet Certain Requirements To Ensure Product Quality And Product Safety. If An Instruction Or Record Is Poorly Documented, Then The Manufacture Or Quality Assurance/Control Of A Product Can Be Negatively Impacted, Potentially Reducing Patient Safety. The Objective Of This Paper To Make A Clear Procedure And Concept To Maintain Gdp For Comply Regulatory Requirements.
\end{abstract}

Keywords: Good Documentation Practice (Gdp), Standard Operating Procedures (Sops), Pharmaceutical Industry

\section{Introduction}

The Definition Of Good Documentation Practice (GDP) Describes Standards By Which Documentation Is Created And Maintained In The Pharmaceutical Industry. Although The U.S. Food And Drug Administration (FDA) Set Some GDP Standards, Others Fall Under The Current Good Manufacturing Practice (Cgmp). All Pharmaceutical, Bioscience And Healthcare Companies, As Well As Their Vendor Partners, Must Observe GDP Or Face Warnings Or Penalties Levied By The FDA.

According To The World Health Organization (WHO), The Purposes Of GDP Are:

- To Define The Specifications And Procedures For All Materials And Methods Of Manufacture And Control.

- To Ensure That All Personnel Concerned With Manufacturing Know What To Do And When To Do It.

- To Ensure That Authorized Persons Have All The Information Necessary To Decide Whether Or Not To Release A Batch Of A Drug For Sale.

- To Ensure The Existence Of Documented Evidence, Traceability And To Provide Records And An Audit Trail That Will Permit Investigation.

- To Ensure The Availability Of The Data Needed For Validation, Review And Statistical Analysis.

Purposeofdocumentations

- Defines Specifications And Procedures For All Materials And Methods Of Manufacture And Control

- Ensures All Personnel Know What To Do And When To Do It

- Ensure That Authorized Persons Have All Information Necessary For Release Of Product

- Ensures Documented Evidence, Traceability, Provide Records And Audit Trail For Investigation

- Ensures Availability Of Data For Validation, Review And Statistical Analysis.

\section{GDP Challenges}

Because Of The Complexities Of Record Keeping In The Pharmaceutical Industry, There Are Inherent Challenges That Companies Face In Regard To GDP. Some Of The Most Common Concerns Compliance Officers Must Keep In Mind Include:

- Lack Of Proper Record-Keeping When Documents Are Transferred From One Department Or Facility To Another.

- Critical Oversight Regarding Document Issue, Data Collection And Document Review.

- Consistent Labeling Which Includes Identification Codes, Document Revision Codes, Product Identification Codes And Product Lot Numbers. 
- $\quad$ Ensuring Proper Security And Storage Of Documents During Review Process.

- $\quad$ Proper And Consistent Identification Of All Documents Through All Processes.

- Ensuring That All Those Whose Signatures Appear On The Documents Understand Why They Signed The Documents As Well As Any And All Responsibilities Associated With The Signing Of The Documents.

\section{Key Qualities Of Regulated Documents As Per Gdp}

Key Qualities of Regulated Documents:

- Concise: Present Information Clearly So It Can Be Easily Understood With No Room For Misinterpretation. For Example, The Date Format "05/06/12" Can Cause Confusion. Use One That Is Unambiguous, Such As "05 Jun 2012.”

- Legible: Information Should Be Readable And Leave No Room For Error (For Example, Hand-Written Data That Are Not Legible May Cloud Data Analysis Or Result In "Missing Data").

- Accurate: Documentation Should Be Error-Free-Properly Reviewed, Verified And Approved. Information Should Be Recorded As An Event Happens And Not After The Fact, So As To Avoid Recording "What You Remember" Rather Than "What Actually Happened."

- Traceable: Documentation Should Be Traceable. Make It Clear Who Logged The Information, What It Was, And When And Why It Was Documented. ${ }^{1}$

Do's and Don'ts with Document

- Use Black Or Blue Permanent, Indelible Ink.

- Make Clear, Complete And Legible Entries.

- $\quad$ Make An Entry When An Event Happens (Not Later).

- Make Corrections That Are Legible And Traceable. For Example, When A Correction Is Required, Put A Line Through The Error, Make The Correction Next To The Error, Include An Explanation (If It Is Not Self-Explanatory), And Initial And Date The Correction.

- If It Is Not Appropriate To Fill In A Space In A Document (Such As An Empty Page), Enter "N/A," Your Initials And The Date So That No Further Information Can Be Added Later.

- Follow Established Standard Operating Procedures (Sops)—For Example, Document Review And Approval Processes, Version Control, And Date And Time Formats, As Well As Record Retention, Change Control, Electronic Signature (If Applicable) And So On.

- $\quad$ Provide Training To Everyone In Company.

- Do Not Use Pencils Or Erasable Ink.

- Do Not Use "Write-Out" Or Any Masking Devices.

- Do Not Make Corrections That Are Not Traceable (For Example, Overwriting Entries With No Date, Initial Or Explanation).

- Do Not Use "Sticky" Notes.

- Do Not Back-Date Or Post-Date.

- Do Not Use Ditto Marks.

- Do Not Use Asterisks That May Cause Confusion (Such As Using The Same Asterisk For Different Footnotes).

- Do Not Transcribe Data.

- Do Not Use Unbound Laboratory Notebooks Without Page Numbers (That Is, Avoid Any Doubt Concerning Missing Pages).

\section{Following Are The Classification Of Documents}

\section{Classification Of Documentation}

- For Organization \& Personnel.

- For Buildings \& Facilities

- For Equipments.

- For Handling Of R.M.\& P.M.

- For Production \& Process Control.

- For Packaging \& Labeling Control.

- For Holding \& Distribution

- For Laboratory Control.

- For Records \& Reports.

- For Return \& Salvaged Finished Products. 


\section{Type Of Documents Used In Pharmaceuticals}

Specifications: As Per MHRA Specifications Describe In Detail The Requirements With Which The Products Or Materials Used Or Obtained During Manufacture Have To Conform. They Serve As A Basis For Quality Evaluation. We Need Specification For:

1. Active And Inactive Materials

2. Primary Printed And Packing Materials

3. Intermediate And Semi Finished Product

4. Finished Product

Sops: It Is A Written, Authorized Functional Instruction Used As A Reference By The Person Responsible For Performance And Are Also Used For Training New Operators In The Performance Of The Procedure.

- Test Method: It Is A Written And Approved Documents Describe The Detailed Testing Procedure.

- List: Documents Contain A Catalog Of Any Object Such As List Of Equipments.

- Certificates Of Analysis: It Is An Authentic Documents Shows The Analytical Reports And Decision Of

Acceptance/Rejections

- Label

- Records

- Organ Gram

- Job Description

- Batch Manufacturing Records: It Is An Important Document Issued For Every Batch Of Product To Assure,

Review And Record Keeping Of Any Product Batch. There Are Following Major Content Of BMR. 1. Name Of Product, Generic Name, Strength, Shelf Life, Manufacturing Date And Exp Date.

2. A Complete List Of Ingredients With Full Description, Codes And Quantity To Be Issued.

3. A Statement For Theoretical Yield And Reconciliation.

4. A Complete MFG And Control Instructions, Sampling And Testing Procedure, Specification And Precaution

To Be Followed.

5. A Statement For Processing Location And Equipment.

6. The Method Or Reference To Method To Be Used For Preparing The Critical Equipment Including Cleaning, Assembling, Calibrating And Sterilizing.

7. Dates And Time Of All Activities

8. Line Clearance Procedure In Every Steps

9. Labeling Control And Specimen For Coding In Primary, Secondary And Tertiary Packing Materials

10. Deviation Record

11. Result Of Examine Made.

Site Master File: It Is A Document, Which Provides All Information Of A Pharmaceutical Plant. There Are Followings Content To Be Needed To Prepare A SMF.

1. General Information, It Includes Information Related To Organization, Mfg Activities, Name And Address, Type Of Products Description Of Site Employee Details External Technical Support, Quality Management System.

2. Personnel, Organizational Chart, Qualification, Experience And Responsibilities Of Key Personnel Training, Health Requirements And Personnel Hygiene Clothing

3. Premises And Equipments: Description Of Manufacturing Area, Nature Of Construction And Finish, Brief Description Of Ventilation, Special Areas, Water System, Maintenance Of Premises, Major Production And Laboratory Equipments, Maintenances Of Equipments, Calibrations And Sanitizations.

4. Documents, Preparations, Revision And Distributions Of Documents,

5. Production, Brief Description Of Production Operations, Handling Of Materials, Handling Of Rejected Materials And Product, Brief Description Of General Policy Of Process Validation.

6. Quality Control, Quality Management System

7. Self Inspection, Self Inspection Program.

8. Change Control, It Is A Document For Review, Approval And Implementation Of Any Change In Validated System, Equipment, Process And Materials Etc.

9. Protocols: A Written Plan Stating How Validation Will Be Conducted And Defining Acceptance Criteria. For Example, The Protocol For A Manufacturing Process Identifies Processing Equipment, Critical Process Parameters/Operating Ranges, Product Characteristics, Sampling, Test Data To Be Collected, Number Of Validation Runs, And Acceptable Test Results. 


\section{Preparation, Issues And Uses Of Documents}

Documents Should Be Carefully And Logically Specify To Prevent Wrong Uses. All Necessary Information's Are Written Unambiguously. Each Document Includes:

1. Company Name

2. Purpose And Title Of Documents

3. Identification No And Revision No.

4. Date Of Authorization

5. Date Of Review

6. Signature Of Prepared By, Checked And Authorized By.

7. Distribution List

8. Page No.

9. Reason For Revision Should Be Documented.

10. Abbreviation And Reference

Each Document Is Clear And Computerized So That It Is Readable, Issued Documents Signed By A Concern Person To Indicate A Verified Issue. Any Correction Is Made By Cutting With Single Line With Signature And Date, Do Not Overwrite. Document To Filled Have A Sufficient Space, Ball Ink Pen Should Be Used For Hand Written Filling.

\section{Hierarchical Document System:}

\section{Steps Involved In Gdp}

The Regulations That A Company Is Responsible For Following (E.G., USFDA/EU GMP/ICH/Schedule M, Etc.) Should Be At The Top Of The Document Pyramid And Should Govern The Directives Of The Sublevels.

The Level Immediately Beneath The Regulations, Level 1 Documents (E.G., The Quality Manual), Should Break The Regulations Into Parts Specific To Those That The Company Is Required To Follow. These Documents Should Establish Overall Principles And Guidelines For How The Company Plans On Developing, Documenting, And Implementing A Ccmp-Compliant Quality System. Top-Level Documents Apply To All Departments Within A Cgmp-Compliant Company And Are Not Specific In Nature.

The Next Level, Level 2, Of Documents In The Hierarchical Document Pyramid Should Further Break Down The Parts Of The Regulations Into Specific Subjects Or Topics. These Documents (E.G., Company Polices) Should Establish Guidelines With Which All Subordinate Level Procedures Must Comply To Ensure Consistency Across Departments.

Level 2 Documents Should Not Provide Specific Directive Instructions Or Forms For Documenting Data But Rather Provide The Overall Intentions And Guidelines Governing Critical Programs Or Systems As Well As Explanation For The Rationale And Program Designs. These Documents Will Apply To All Departments Within A GMP-Compliant Company.

Sops Should Be The Next Level In The Document Hierarchy After Company Policy Documents. These Types Of Documents Should Provide Specific Step-By-Step Instructions For Performing The Operational Tasks Or Activities That Were Talked About In The Previous Levels (For Example: SOP Titled 'Writing, Revising, Numbering, And Distributing Controlled Documents'). Level 3 Documents (I.E., Sops) Should Be Department Specific Or Function Specific.

The Last Level Of Documents In A Document Hierarchical Structure Are Level 4 Documents. These Documents Are The Most Specific In Nature, (E.G., Batch Record, Test Methods, Validation Procedures). They Apply To A Specific Department, Product, Equipment, Or Process. Level 4 Documents Provide Step-By-Step Instructions For Production-Related Tasks And Activities As Well As Provide A Means For Documenting Such Tasks Using, For Example, Data Sheets, Forms, Or Batch Records. The Details Outlined In These Documents May Override Directions Given In Other Level Documents. (For Example: The Company's Documentation SOP May State That Numbers Be Rounded Off To Three Significant Figures; The Batch Record, On The Other Hand, May State That All Numbers Be Expressed In Scientific Notation. Thus, Instructions In Level 4 Documents, Which Are Specific To A Particular Process, Can Overrule The Instruction Mentioned In Level 3 Documents, Which Are General In Nature. The Document Hierarchy Pyramid Is One Way Of Organizing A Company's Documents.

\section{GDP Steps:}

\section{- Initial/Date}

All Entries To A Cgmp Document Must Be Accompanied By The Identity Of The Person (Initials Or Signature) And The Date That The Entry Was Made. This Is Required By The Code Of Federal Regulations (Cfrs) And Serves As A Tracking Method To Determine That A Task Was Indeed Performed And Who Did The Work. 
Initials Are The Accepted Standard Method Of Identification. However, Some Operations Require A Signature. For Example, An "Approved By" Space Must Be Filled With A Signature, Not Initials.

For Larger Companies With People That Have The Same Initials You Will Need To Make A Standard. Examples Of Your Signature And Initials Will Also Be Recorded By The Various Companies.

\section{- Recording Time}

Military Time: Two (2) Digits To Indicate The Hour (00 To 23) Followed By Two (2) Digits To Indicate Eh Minutes (00 To 59) Example 0850 And 1750

Meridian Time: One Or Two Digits To Indicate The Hour (1 Or 12) Followed By Two Digits To Indicate The Minutes (00 To 59) Then The Morning (AM) Or Afternoon (PM) Designation. Example 8:50am Or 5:50pm (Notice That It Is The Same As The Above)

Your Company Will Probably Have A Standard That They Accept; You Will Need To Inquire As To What That Is.

\section{- Corrections:}

No Handwritten Changes Or Corrections Will Be Made To The Printed Text Of An Approved Cgmp Document. Consult With Your Supervisor If You Discover An Error. Any Changes Required To An Approved Cgmp Documents Shall Be Implemented Through The Established Quality System.

When Making A Correction To A Manually Recorded Entry On A Controlled Document Performs The Following Steps:

1. Place A Single Line Through The Incorrect Entry

2. Initial And Date The Adjacent To The Cross-Out

3. Enter The Correct Data Near The Original Entry

4. The Mistake Must Still Be Legible Through The Cross-Out.

5. Date Of The Correction Is The Date The Correction Was Made, Not The Date The Error Was Made.

\section{- Performed By}

Performance Of A Stip Must Be Documented At The Time Of Completing The Stip And Prior To Moving On To The Next Stop. Do Not Execute A Stip If The Manufacturing Procedure Is Not Available For Documenting Necessary Data At The Time Of Execution. The Following Personnel May Initial And Date The "Performed By" Space

1. Personnel Already Proficient In The Task Performed, Or

2. Personnel Who Are In Training Under The Supervision Of Their Qualified Trainer

\section{- Recorded By}

The "Recorded By" Space Is Used If The Operator Performing The Operation Is Unable To Initial And Date Immediately, Due To Working In A Confined Or Restricted Space, Such As A Laminar Air Flow Hood. This Situation Is The Only Exception To The "Performed By" Rule. Data Must Then Be Recorded By Another Person Watching The Operation. The Person Recording Data Must Initial And Date The "Recorded By" Space Prior To Moving On To The Next Step.

\section{- Verified By}

Verification Shall Be Performed Prior To Moving On To The Next Step. Operators Executing A Task Cannot Verify Their Own Action. At Least One Other Person Must Review Documentation For Accuracy. Personnel May Initial Or Sign And Date The "Verified By" Space If

1. They Witnessed That A Task, Operation, Or Procedure Was Performed Per Written Instructions And Accurately Documented

2. They Are Already Proficient In The Task Performed

\section{- Deviations}

If You Deviate From A Written Procedure, You Must

1. Notify Your Supervisor

2. Document The Deviation Using The Appropriate Quality System

\section{- Missing Data}

If Information Is Not Entered At The Time Or Completing The Step, The Blank Entry Shall Be Marked By An Asterisk Or Similar Notation. The Use Of Each Notation Is Limited To One Per Page. Comments 
Good Documentation Practice (GDP): Coordinate Regulatory Requirements In Pharmaceutical .....

Explaining The Reason Information Is Missing, Along With The Proper Information (E.G.,M Date Event Actually Occurred), Shall Be Documented On The Same Page Of The Record. The Explanation Shall Be Initialed And Dated At The Time Of Recording.

\section{- Voiding Records}

On Occasion, Errors Made In The Execution Of Making An In-Process Material Such As A Buffer And All The Proper Documentation Was Completed. However, Because Of The Error, The Decision Is Made To Scrap The Material And Start All Over With New In-Process Material. The Original Document Would Need To Be Voided And Attached To The Document Replacing It. The Documents Are Voided To Prevent Confusion Or Mix-Ups With The Correct Document. When Voiding A Document Do The Following;

1. Get A Supervisor And Quality Assurance (QA) Approval

2. Write "Void" Across The Front Of The Document And Include Initial And Date.

\section{- Recreating And Rewriting Records}

Recreating Or Rewriting Records Should Be Avoided. It May Be Necessary To Do This. The Supervisor And QA Approvals Are Required When Recreating Records. It Is Important To Identify The Recreated Document As "Rewrite" And To Reference The Sources Of The Information. Records Can Be Recreated Only When:

1. The Original Record Is Illegible

2. An Incorrect Form Or Document Was Used

3. The Record Is Reparable

4. The Original Was In A Format That Would Not Keep (Thermal Paper Strips)

\section{- Rounding Of Rules}

The Following Rules Apply To Rounding Off:

1. In A Series Of Calculations, Carry The Extra Digits Through To The Final Result, Then Round Off.

2. If The Digit To Be Removed $<5$, The Preceding Digit Stays The Same. For Example, 1.84 Rounds To 1.8.

3. If The Digit To Be Removed $>\mathrm{Or}=5$, The Preceding Digit Is Increased By 1. For Example, 1.85 Rounds To 1.9 .

- Approved By:

Signature Of A Qualified Individual (Supervisor Or Designee) Indicating That The Information Documented Is Complete, Accurate, And Acceptable.

\section{Gdp Coordinate With Regulatory Requirements}

The Coordination Requirements For GDP To Meet The Regulatory Requirements:

\section{- Site Master File}

The Manufacturer Should Prepare A Succinct Document In The Form Of A 'Site Master File,' Containing Specific And Factual GMP About The Production And/Or Control Of Pharmaceutical Manufacturing Procedures Carried Out At The Premises. It Should Contain The Descriptions Of The Following:

\section{General Information:}

1. Brief Information On The Firm

2. Pharmaceutical Manufacturing Activities, As Permitted By The Licensing Authority

3. Other Manufacturing Activities, If Any, Carried Out On The Premises

4. Type Of Products Licensed For Manufacture, With Flowcharts Detailing Procedure And Process Flow

5. Number Of Employees Engaged In The Production, Quality Control, Storage And Distribution

6. Use Of Outside Scientific, Analytical, Or Other Technical Assistance In Relation To Manufacture And Analysis

7. Short Description Of The Quality Management System Of The Firm

8. Products Details Registered With Foreign Countries

- Personnel:

1. Organizational Chart Showing The Arrangements For Quality Assurance, Including Production And Quality Control

2. Qualification, Experience, And Responsibilities Of Key Personnel

- Premises:

1. Simple Plan Or Description Of Manufacturing Areas Drawn To Scale

2. Nature Of Construction And Fixtures/Fittings 
3. Brief Description Of Ventilation Systems. More Details Should Be Given For Critical Areas With Potential Risk Of Airborne Contamination (Schematic Drawing Of Systems). Classification Of The Rooms Used For The Manufacture Of Sterile Products Should Be Mentioned.

4. Special Areas For The Handling Of Highly Toxic, Hazardous, And Sensitizing Materials.

5. Brief Description Of The Water System (Schematic Drawings Of Systems), Including Sanitation.

6. Description Of Planned Preventive Maintenance Programs For Premises And Of The Recording System.

- Equipment:

1. Brief Description Of Major Equipment Used In Production And In The Quality Control Laboratories (A List Of Equipment Required)

2. Description Of Planned Preventive Maintenance Programs For Equipment And Of The Recording System

3. Qualification And Calibration, Including The Recording Systems, And Arrangements For Computerized Systems Validation

- Sanitation:

Written Specifications And Procedures For Cleaning Manufacturing Areas And Equipment

Documentation:

1. Arrangements For The Preparation, Revision, And Distribution Of Documents

2. Necessary Documentation For The Manufacture

3. Any Other Documentation Related To Product Quality That Is Not Mentioned Elsewhere (E.G., Regarding Microbiological Control Of Air And Water)

Production:

1. Brief Description Of Production Operations Using, Wherever Possible, Flow Sheets And Charts Specifying Important Parameters

2. Arrangements For The Handling Of Starting Materials, Packaging Materials, And Bulk And Finished Products; This Includes The Arrangements For Sampling, Quarantine, Release, And Storage.

3. Arrangements For The Handling Of Rejected Materials And Products.

4. Brief Description Of The General Policy For Process Validation.

Quality Control:

Description Of The Quality Control System And Of The Activities Of The Quality Control Department. Procedures For The Release Of The Finished Products.

- Loan License Manufacture And Licensee:

Description Of The Way In Which Compliance With GMP By The Loan Licensee Should Be Assessed.

- Distribution, Complaints, And Product Recall:

1. Arrangements And Recording System For Distribution

2. Arrangements For The Handling Of Complaints And Product Recalls

- Self Inspection:

Short Description Of The Self-Inspection System, Indicating Whether An Independent And Experienced External Expert Is To Be Involved In Evaluating The Manufacturer's Compliance With GMP In All Aspects Of Production

- Export Of Drugs

1. Products Exported To Different Countries

2. Complaints And Product Recall, If Any

\section{- Documentation System And Specifications}

Documentation Is An Essential Part Of The Quality Assurance System And, As Such, Should Be Related To All Aspects Of GMP. Its Aim Is To Define The Specifications For All Materials And The Method Of Manufacture And Control, To Ensure That All Personnel Concerned With Manufacture Have The Information Necessary To Decide Whether Or Not To Release A Batch Of A Drug For Sale, And To Provide An Audit Trail That Will Permit Investigation Of The History Of Any Suspected Defective Batch. The Specifications Should Describe In Detail The Requirements With Which The Products Or Materials Used Or Obtained During Manufacture Have To Conform. They Serve As A Basis For Quality Evaluation.

Manufacturing Formulae And Processing And Packaging Instructions Should Specify All The Starting Materials Used And Describe All Processing And Packaging Operations. Procedures Should Give Directions For Performing Certain Operations, E.G., Cleaning, Clothing, Environmental Control, Sampling, Testing, And Equipment Operation. Records Should Provide A History Of Each Batch Of Product, Including Its Distribution, And Also Of All Other Relevant Circumstances Pertinent To The Quality Of The Final Product.

Written Records Should Be Maintained So That Data Can Be Used For Evaluating, At Least Annually, The Quality Standards Of Each Drug Product To Determine The Need For Changes In Drug Product Specifications Or Manufacturing Or Control Procedures. Written Procedures Should Be Established And Followed For Such Evaluations And Must Include Provisions For: 
1. A Review Of A Representative Number Of Batches, Whether Approved Or Rejected And, Where Applicable, The Records Associated With The Batch.

2. A Review Of Complaints, Recalls, And Returned Or Salvaged Drug Products, And Of The Investigations Conducted.

All Documents Related To The Manufacture Of Intermediates, Active Pharmaceutical Ingredients (API), And Finished Products Should Be Prepared, Reviewed, Approved, And Distributed According To Written Procedures. Such Documents Can Be Paper-Based Or In Electronic Form. Documents Should Be Approved, Signed, And Dated By The Appropriate Responsible Persons. No Document Should Be Changed Without Authorization And Approval.

Each Specification For Raw Materials, Intermediates, Final Products, And Packing Materials Should Be Approved And Maintained By The Quality Control Department. Periodic Revisions Of The Specifications Must Be Carried Out Whenever Changes Are Necessary.

The Issuance, Revision, Superseding, And Withdrawal Of All Documents Should Be Controlled, With Maintenance Of Revision Histories. When A Document Has Been Revised, Systems Should Be Operated To Prevent Inadvertent Use Of Superseded Documents. Superseded Documents Should Be Retained For A Specific Period Of Time.

Periodic Revisions Of The Specifications May Be Necessary To Comply With New Editions Of The National Pharmacopoeia Or Other Official Compendia.

Documents Should Have Unambiguous Contents: The Title, Nature, And Purpose Should Be Clearly Stated. They Should Be Laid Out In An Orderly Fashion And Be Easy To Check. Reproduced Documents Should Be Clear And Legible. The Process Of Reproduction Of Working Documents From Master Documents Must Not Allow Any Error To Be Introduced Through The Reproduction Process.

A Procedure Should Be Established For Retaining All Appropriate Documents (E.G., Development History Reports, Scale-Up Reports, Technical Transfer Reports, Process Validation Reports, Training Records, Production Records, Control Records, And Distribution Records). The Retention Periods For These Documents Should Be Specified.

All Production, Control, And Distribution Records Should Be Retained For At Least 1 Year After The Expiry Date Of The Batch. For Apis With Retest Dates, Records Should Be Retained For At Least 3 Years After The Batch Is Completely Distributed.

Documents Should Not Be Handwritten; However, Where Documents Require The Entry Of Data, These Entries May Be Made In Clear, Legible, Indelible Handwriting. Sufficient Space Should Be Provided For Such Entries. Any Alteration Made To The Entry On A Document Should Be Signed And Dated; The Alteration Should Permit The Reading Of The Original Information. Where Appropriate, The Reason For The Alteration Should Be Recorded.

During The Retention Period, Originals Or Copies Of Records Should Be Readily Available At The Establishment Where The Activities Described In Such Records Occurred. Records That Can Be Promptly Retrieved From Another Location By Electronic Or Other Means Are Acceptable.

Data May Be Recorded By Electronic Data Processing Systems Or Photographic Or Other Reliable Means, But Detailed Procedures Relating To The System In Use Should Be Available And The Accuracy Of The Records Should Be Checked. If Documentation Is Handled By Electronic Data Processing Methods, Only Authorized Persons Should Be Able To Enter Or Modify Data In The Computer, And There Should Be A Record Of Changes And Deletions. Access Should Be Restricted By Passwords Or Other Means And The Result Of Entry Of Critical Data Should Be Independently Checked. Batch Records That Are Electronically Stored Should Be Protected By Back-Up Transfer Onto Magnetic Tape, Microfilm, Paper, Or Other Means.

Specifications Should Be Established And Documented For Raw Materials, Intermediates (Where Necessary), And API/Formulations, As Well As For Labeling And Packaging Materials. In Addition, Specifications May Be Appropriate For Certain Other Materials, Such As Process Aids, Gaskets, Or Other Materials Used During The Production Of Intermediates Or API/Formulations That Could Critically Impact On Quality. Acceptance Criteria Should Be Established And Documented For In-Process Controls.

If Electronic Signatures Are Used On Documents, They Should Be Authenticated And Secure.

\section{- Equipment Cleaning And Use Record}

Records Of Major Equipment Use, Cleaning, Sanitization And/Or Sterilization, And Maintenance Should Show The Date, Time (If Appropriate), Product, And Batch Number Of Each Batch Processed In The Equipment And The Name And Signature Of The Person Who Has Performed The Cleaning And Maintenance. The Persons Performing And Double-Checking The Cleaning And Maintenance Should Date And Sign Or Initial The Log, Indicating That The Work Was Performed. Entries In The Log Should Be In Chronological Order.

Cross-Contamination Should Be Avoided By Appropriate Technical Or Organizational Measures, For Example: 
1. Production In Segregated Areas (Required For Products Such As The Penicillins, Live Vaccines, Live Bacterial Preparations, And Some Other Biologicals), Or By Campaign (Separation In Time) Followed By Appropriate Cleaning

2. Providing Appropriate Air-Locks And Air Extraction

3. Minimizing The Risk Of Contamination Caused By Recirculation Or Re-Entry Of Untreated Or Insufficiently Treated Air

4. Keeping Protective Clothing Inside Areas Where Products With Special Risk Of Cross-Contamination Are Processed

5. Using Cleaning And Decontamination Procedures Of Known Effectiveness, As Ineffective Cleaning Of Equipment Is A Common Source Of Cross-Contamination

6. Using 'Closed Systems' Of Production

7. Testing For Residues And Use Of Cleaning Status Labels On Equipment

If Equipment Is Dedicated To Manufacturing One Intermediate Or API, Then Individual Equipment Records Of Different Activities Like Cleaning, Maintenance, Batch Log, Etc., Are Not Necessary, Provided The Batch Record Has Complete Traceability Of This Information. In Case Of Formulation Manufacturing, The Appropriate Cleaning Procedure Should Be Established To Ensure Removal Of Any Residue Of The Previous Product.

- Records Of Raw Materials, Intermediates, Labeling, And Packaging Materials

1. Records Should Be Maintained, Including:

2. The Name Of The Manufacturer; Identity And Quantity Of Each Shipment Of Each Batch Of Raw Materials, Intermediates, Or Labeling And Packaging Materials; The Name Of The Supplier; The Supplier's Control Number(S) (If Known) Or Other Identification Number; The Number Allocated On Receipt; And The Date Of Receipt;

3. The Results Of Any Test Or Examination Performed And The Conclusions Derived From This;

4. Records Tracing The Use Of Materials;

5. Documentation Of The Examination And Review Of Labeling And Packaging Materials For Conformity With Established Specifications;

6. The Final Decision Regarding Rejected Raw Materials, Intermediates, Or Labeling And Packaging Materials.

7. Starting Materials In The Storage Area Should Be Appropriately Labeled. Labels Should Bear At Least The Following Information:

8. The Designated Name Of The Product And The Internal Code Reference, Where Applicable

9. The Batch Number Given By The Supplier And, On Receipt, The Control Or Batch Number (If Any) Given By The Manufacturer; These Must Be Documented So As To Ensure Traceability

10. The Status Of The Contents (E.G., On Quarantine, On Test, Released, Rejected, Returned, Recalled, Etc.)

11. Where Appropriate, An Expiry Date Or A Date Beyond Which Retesting Is Necessary

12. Master (Approved) Labels Should Be Maintained For Comparison With Issued Labels.

- Master Production Instructions/Master Production And Control Records (MPCR)/Master Formula Card (MFC)

To Ensure Uniformity From Batch To Batch, Master Production Instructions For Each Intermediate Or API/Finished Product Should Be Prepared, Dated, And Signed By One Person And Independently Checked, Dated, And Signed By A Second Person In The Quality Unit(S).

Competent Persons Experienced In Production And Quality Control Should Be Responsible For The Content And Distribution Within The Firm Of Instructions And Master Formulae. These Should Be Duly Signed And Dated.

Outdated Master Formulae Should Be Withdrawn But Retained For Reference. Copies Of The Master Formula Should Be Prepared In A Manner That Will Eliminate Any Possibility Of Transcription Error.

In Certain Circumstances, For Example, In The First Production Runs Following Pilot Development, The Master Formula Might Need To Be Amended. Any Amendments Must Be Formally Authorized And Signed By Competent Person(S). The Amended Document Should Be Replaced At The Earliest Opportunity By A Newly Prepared Master Formula.

Processing Should Be Carried Out In Accordance With The Master Formula. Master Production Instructions Should Include:

1. The Name Of The Intermediate/API/Formulation Being Manufactured And An Identifying Document Reference Code, If Applicable

2. A Complete List Of Raw Materials And Intermediates (Designated By Names Or Codes Sufficiently Specific To Identify Any Special Quality Characteristics) 
3. An Accurate Statement Of The Quantity Or Ratio Of Each Raw Material Or Intermediate To Be Used, Including The Unit Of Measure. Where The Quantity Is Not Fixed, The Calculation For Each Batch Size Or Rate Of Production Should Be Included. Variations To Quantities Should Be Included Wherever Justified

4. The Production Location And Major Production Equipment To Be Used

5. Detailed Production Instructions

6. Where Appropriate, Special Notations And Precautions To Be Followed, Or Cross-References To These

7. Instructions For Storage Of The Intermediate Or API/Semi-Finished Formulations To Assure Its Suitability For Use; Instructions Should Cover The Labeling (Specimen Labels And Packaging Materials And Special Storage Conditions With Time Limits, Where Appropriate).

\section{- Batch Production Records/Batch Production And Control Records (BPCR)/Batch Manufacturing Record (BMR)}

Batch Production Records Should Be Prepared For Each Intermediate And API/Formulation And Should Include Complete Information Relating To The Production And Control Of Each Batch. The Batch Production Record Should Be Checked Before Issuance To Assure That It Is The Correct Version And A Legible Accurate Reproduction Of The Appropriate Master Production Instruction. If The Batch Production Record Is Produced From A Separate Part Of The Master Document, That Document Should Include A Reference To The Current Master Production Instruction Being Used.

Before Any Processing Begins, A Check Should Be Performed And Recorded To Ensure That The Equipment And Workstation Are Clear Of Previous Products, Documents, Or Materials Not Required For The Planned Process And That The Equipment Is Clean And Suitable For Use.

These Records Should Be Numbered With A Unique Batch Or Identification Number And Dated And Signed When Issued. In Continuous Production, The Product Code Together With The Date And Time Can Serve As The Unique Identifier Until The Final Number Is Allocated.

The Batch Number Should Be Immediately Recorded In A Logbook Or By Electronic Data Processing System. The Record Should Include Date Of Allocation, Product Identity, And Size Of Batch.

Documentation Of Completion Of Each Significant Step In The Batch Production Records (Batch Production And Control Records) Should Include:

1. Dates And, When Appropriate, Times

2. Identity Of Major Equipment Used (E.G., Reactors, Driers, Mills, Etc.)

3. Specific Identification Of Each Batch, Including Weights, Measures, And Batch Numbers Of Raw Materials, Intermediates, Or Any Reprocessed Materials Used During Manufacturing

4. Actual Results Recorded For Critical Process Parameters

5. Any Sampling Performed

6. Signatures Of The Persons Performing And Directly Supervising Or Checking Each Critical Step In The Operation

7. In-Process And Laboratory Test Results

8. Actual Yield At Appropriate Phases Or Times

9. Description Of Packaging And Label

10. Representative Label (Commercial Supply)

11. Any Deviation Noted, Its Evaluation, And Investigation Conducted (If Appropriate) Or Reference To That Investigation (If Stored Separately)

12. Results Of Release Testing

13. All Analytical Records Relating To The Batch, Or A Reference That Will Permit Their Retrieval

14. A Decision For The Release Or Rejection Of The Batch, With The Date And Signature Of The Person Responsible For The Decision

15. The Production Record Review

Production And Quality Control Records Should Be Reviewed As Part Of The Approval Process Of Batch Release. Any Divergence Or Failure Of A Batch To Meet Its Specifications Should Be Thoroughly Investigated. The Investigation Should, If Necessary, Extend To Other Batches Of The Same Product And Other Products That May Have Been Associated With The Specific Failure Or Discrepancy. A Written Record Of The Investigation Should Be Made And Should Include The Conclusion And Follow-Up Action. The Following Information Should Be Recorded At The Time Each Action Is Taken (The Date Must Be Noted And The Person Responsible Should Be Clearly Identified By Signature Or Electronic Password):

1. The Name Of The Product, The Batch Number And The Quantity Of Product To Be Packed, As Well As The Quantity Actually Obtained And Its Reconciliation

2. The Date(S) And Time(S) Of The Packaging Operations

3. The Name Of The Responsible Person Carrying Out The Packaging Operation

4. The Initials Of The Operators Of The Different Significant Steps 
5. The Checks Made For Identity And Conformity With The Packaging Instructions, Including The Results Of In-Process Controls

6. Details Of The Packaging Operations Carried Out, Including References To Equipment And The Packaging Lines Used And, When Necessary, Instructions For Keeping The Product Unpacked Or A Record Of Returning Product That Has Not Been Packaged To The Storage Area

7. Whenever Possible, The Regular Check For Correctness Of Printing (E.G. Batch Number, Expiry Date And Other Additional Overprinting) And Specimen Samples Collected

8. Notes On Any Special Problems, Including Details Of Any Deviation From The Packaging Instructions, With Written Authorization By An Appropriate Person

9. The Quantities And Reference Number Or Identification Of All Printed Packaging Materials And Bulk Product Issued, Used, Destroyed, Or Returned To Stock And The Quantities Of Product Obtained; This Is Necessary To Permit An Adequate Reconciliation.

- Laboratory Control Records

Laboratory Control Records Should Include Complete Data Derived From All Tests Conducted To Ensure Compliance With Established Specifications And Standards, Including Examinations And Assays, As Follows:

1. A Description Of Samples Received For Testing, Including The Material Name Or Source, Batch Number And, Where Appropriate, The Manufacturer And/Or Supplier; Alternatively, Other Distinctive Code, Date Of Sample Taken And, Where Appropriate, The Quantity Of The Sample And Date The Sample Was Received For Testing

2. A Statement Of, Or Reference To, Each Test Method Used

3. A Statement Of The Weight Or Measure Of Sample Used For Each Test As Described By The Method; Data On, Or Cross-Reference To, The Preparation And Testing Of Reference Standards, Reagents, And Standard Solutions

4. A Complete Record Of All Raw Data Generated During Each Test, In Addition To Graphs, Charts, And Spectra From Laboratory Instrumentation, All Properly Identified To Show The Specific Material And The Batch Tested

5. A Record Of All Calculations Performed In Connection With The Test Including, For Example, Units Of Measure, Conversion Factors, And Equivalency Factors

6. A Statement Of The Test Results And How They Compare With Established Acceptance Criteria

7. The Signature Of The Person Who Performed Each Test And The Date(S) On Which The Tests Were Performed

8. The Date And Signature Of A Second Person, Showing That The Original Records Were Reviewed For Accuracy, Completeness, And Compliance With Established Standards.

Complete Records Should Also Be Maintained For:

1. Any Modifications To An Established Analytical Method

2. Periodic Calibration Of Laboratory Instruments, Apparatus, Gauges, And Recording Devices

3. All Stability Testing Performed On Apis/Formulations

4. Out-Of-Specification (OOS) Investigations

Complete Records Should Be Maintained Of Any Testing And Standardization Of Laboratory Reference Standards, Reagents, And Standard Solutions; Record Should Also Be Maintained Of Periodic Calibration Of Laboratory Instruments, Apparatus, Gauges, And Recording Devices.

\section{- Batch Production Record Review}

Written Procedures Should Be Established And Followed For The Review And Approval Of Batch Production And Laboratory Control Records, Including Packaging And Labeling, To Determine Compliance Of The Intermediate Or API With Established Specifications Before A Batch Is Released Or Distributed.

Batch Production And Laboratory Control Records Of Critical Process Steps Should Be Reviewed And Approved By The Quality Unit(S) Before An API Batch Is Released Or Distributed. Production And Laboratory Control Records Of Non-Critical Process Steps Can Be Reviewed By Qualified Production Personnel Or Other Units, Following Procedures Approved By The Quality Unit(S).

All Deviation, Investigation, And OOS Reports Should Be Reviewed As Part Of The Batch Record Review Before The Batch Is Released.

The Quality Unit(S) Can Delegate To The Production Unit The Responsibility And Authority For Release Of Intermediates, Except For Those Shipped Outside The Control Of The Manufacturing Company.

Distribution Record Should Be Maintained And Must Include The Batch Number; Quantity Produced; Name, Address, And Contact Details Of Customer; Quantity Supplied; And Date Of Supply. 


\section{General Requirements For Gdp}

\section{Table 1: General Requirements For GDP}

\begin{tabular}{|c|c|}
\hline General Elements & GDP Requirements \\
\hline Clearly Written Documentation: & $\begin{array}{l}\text { All Documents Must Be Accurate And Written In A Manner That Prevents Errors And } \\
\text { Ensures Consistency. If Documents Are To Be Used Together, E.G. An SOP And A } \\
\text { Form, Then Each Should Reference The Other. } \\
\text { Ensure There Is Traceability Between Two Or More Documents/Records Using Formal } \\
\text { Document Numbers Or Record Identification. }\end{array}$ \\
\hline Using Indelible Ink: & $\begin{array}{l}\text { All Records Must Be Filled Out In Indelible Ink For Long Term Legibility. Do Not Use } \\
\text { Pencil Or Ink That Can Be Erased. } \\
\text { Colour Should Be Specified By The Company GDP Procedure; Often This Is Limited } \\
\text { To Blue Or Black Because Historically Copy/Scanning Technology Was Limited In } \\
\text { Reproduction Quality. However, This Is Less Of A Factor With The Advent Of High } \\
\text { Resolution Scanners And Colour Copiers. } \\
\text { Consistent Use Of Blue And Black Ink On GMP Documentation Provides A More } \\
\text { Professional Perception Of Your Organisation. }\end{array}$ \\
\hline Legible Handwritten Entries: & $\begin{array}{l}\text { A Document Is Unusable If It Cannot Be Read, So Care Must Be Taken To Ensure That } \\
\text { Handwriting Is Legible. All Entries Must Be Made At The Time The Tasks Are } \\
\text { Performed And Should Be Legibly Signed And Dated. } \\
\text { The Same Is True Of Electronic Documents And Records - Language Should Be Clear } \\
\text { And Unambiguous. }\end{array}$ \\
\hline Reviewing And Approving & $\begin{array}{l}\text { Documents And Records Should Be Reviewed By Someone Who Did Not Perform The } \\
\text { Task To Ensure That The Information Is Correct And Accurate. A Signature And Date } \\
\text { By The Reviewer/Approver Confirms That A Review Has Taken Place. } \\
\text { Unsigned Documents Or Records Are Incomplete And Should Not Be Used To Perform } \\
\text { Any Task Or Considered As Evidence Of A Completed Task. }\end{array}$ \\
\hline Staff Signatures & $\begin{array}{l}\text { Handwritten Signatures Must Be Unique To The Individual And Listed Within The Site } \\
\text { Signature Register To Ensure That The Signature Is Traceable To A Member Of Staff } \\
\text { (Or Contractor). Staff Are Not Permitted To Sign For Another Member Of Staff Unless } \\
\text { Delegated. Signatures Must Never Be Forged. } \\
\text { The Management Of The Signature Record Should Be Governed By A Procedure And } \\
\text { Routinely Reviewed So That It Remains Current - New Staff Should Sign The } \\
\text { Signature Register During Induction, The Signature Register Must Indicate The Date } \\
\text { Staff Exit The Company. } \\
\text { Electronic Signatures Must Meet The Same General Documentation Requirements - } \\
\text { Refer To EU Annex 11: Computerised Systems Or PIC/S Annex 11: Computerized } \\
\text { Systems For Additional Regulatory Requirements. }\end{array}$ \\
\hline Signed Delegation Of Responsibility & $\begin{array}{l}\text { In The Event That A Critical Member Of Staff Is Absent For A Time, They Must } \\
\text { Delegate Responsibility To Another Qualified Person. The Delegation Must Be Either: } \\
\text { Proceduralised In A Document (SOP, WI Etc.), Or } \\
\text { Documented With Names Of All People Involved And Signed By The Person That Is } \\
\text { Delegating Their Responsibility. The Delegation Should Also Be Approved With The } \\
\text { Signature Of A More Senior Member Of Staff. }\end{array}$ \\
\hline Page Numbering & $\begin{array}{l}\text { GMP Documents Should Have Page Numbers Using The Following Standard 'X Of Y' } \\
\text { To Indicate The Total Number Of Pages In A Document. }\end{array}$ \\
\hline
\end{tabular}

\section{Communication Styles Used In Gdp}

Table 2: The Following Table Contains Suggestions For Communication Styles Useful For GDP

\begin{tabular}{|c|c|}
\hline Actions & How They Help \\
\hline $\begin{array}{l}\text { Using Words That Everyone Can Understand (Reduce Jargon } \\
\text { Or Abbreviations) }\end{array}$ & $\begin{array}{l}\text { Unfamiliar Words Reduce The Reader's Understanding Of What Is } \\
\text { Written. It Can Also Interrupt Their Flow Of Learning If They Need To } \\
\text { Search For The Meaning Of A Word. Therefore, Jargon Or Abbreviations } \\
\text { Should Be Avoided If Possible, Unless Well Known To The Audience. } \\
\text { Definitions Of Jargon Or Abbreviations Should Always Be Included In } \\
\text { The Document For Reference. This Is Most Effectively Done By Included } \\
\text { The Definitions In A Table Format, At The Start Or End Of The } \\
\text { Document. } \\
\text { There Is Often Company-Specific Jargon That Develops Within A } \\
\text { Company Or On A Site That May Be Very Confusing To Outsiders Or } \\
\text { New Staff - Prepare A List Of These Terms That Is Easily Accessible } \\
\text { And Include Within The Induction Procedure And For Audit Situations. }\end{array}$ \\
\hline Using Words With Unambiguous Meaning & $\begin{array}{l}\text { The English Language Is Full Of Descriptive Words Which Can Have } \\
\text { Different Meanings Depending On The Context, The Understanding Of } \\
\text { The Reader And Even Cultural Differences. For This Reason, Words } \\
\text { Should Be Chosen Very Carefully. }\end{array}$ \\
\hline Using Whitespace & $\begin{array}{l}\text { Ensure That The Contents Of The Document Are Not Squeezed Into A } \\
\text { Smaller Area Just To Limit Page Numbers. Documents With Small } \\
\text { Margins And No Spaces Between Paragraphs And Headings Can Be } \\
\text { Difficult To Look At, Hard And Slower To Read. Space The Contents Out } \\
\text { So That The Type/Font Is Easy To Read For All Users (Consider The } \\
\text { Overall Audience Age, Or Potential Colour Blindness Or Dyslexia). }\end{array}$ \\
\hline
\end{tabular}




\begin{tabular}{|l|l|}
\hline Providing Enough Detail To Make Sense Of It In The Future & $\begin{array}{l}\text { When Creating A Document, Consider The Context In Which The } \\
\text { Document May Be Used In The Future And Whether The Reader Has } \\
\text { Enough Background Information. However, Too Much Non-Critical } \\
\text { Information Can Also Detract From The Document And Make It Too } \\
\text { Wordy. }\end{array}$ \\
\hline Using Pictorial Or Graphical Aids (Including Tables) & $\begin{array}{l}\text { Many People Remember Information Best When There Is A Strong } \\
\text { Visual Prompt, Such As A Diagram. When The Document Has To Be } \\
\text { Wordy, Consider Using Tables To Structure The Information So It Is Less } \\
\text { Overwhelming To The Reader. }\end{array}$ \\
\hline Previous Experience And Expectations & $\begin{array}{l}\text { The Level Of Detail, Written Style And Type Of Document Should All Be } \\
\text { Ruled By The Documents Target Audience. }\end{array}$ \\
\hline Consistent Wording To Avoid Confusion & $\begin{array}{l}\text { Referring To Something By Two Different Names, Even If Only Slightly } \\
\text { Different, Can Be Confusing. }\end{array}$ \\
\hline Consistent Styles Templates & $\begin{array}{l}\text { Consistency With Styles Will Give Any Document A Greater Sense Of } \\
\text { Professionalism. }\end{array}$ \\
\hline
\end{tabular}

\section{Document Control}

Initially Document Is Prepared By Concern Department As Draft And Draft Is Reviewed By Dept. Head And Final Draft Is Send To QA Department That Convert A Draft To A Final Documents Checked And Approved By Authorize Person. Control Copies Are Issued To Concern Department And Issuance Records Are Maintained. After Approval Of Documents Such As Sops Quality Assurance Must Ensure That All Users/Concerned Department Gets Training Before The Implementation Of The Sops Record Of Such Training Must Be Maintained. A Training Co-Coordinator Preferably The Head Of User Department Or Any Designated Individuals Shall Be Responsible For Organizing The Training. After Successful Implementation Of Training On Any Sops, The Sops Become Effective.

Original Sops Are Stamped As "MASTER COPY" With Red Ink, Master Copy Are Stored Under Supervision And Photocopy Of Master Copy Duly Stamped As "CONTROL COPY" In Blue Color. Sops Distribution List Should Be Maintained For Issuance Records, Change In Sops Need To Initiated Change Request And All Issue Copies Are Retrieve And New One Implemented With Training.

\section{- Record Control}

GDP Procedure Should Describe The Types Of Workbooks/Notebooks That May Be Used - Typically These Are Hard-Covered With Sown/Sturdy Binding; Avoid Spiral Bound Workbooks Or Logbooks As Pages May Be Removed.

In An Emergency, If No Official Means To Record An Observation Is Available, Then:

1. Initial, Date And Provide A Comment On The Paper Record Of The Observation And Attach To The Official Hardcopy Record As Soon As Possible.

2. Transcribe And Attach The Data To The Official Record And Annotate 'Transcribed, See Attached Original'. The Transcription Must Be Signed And Dated By The Preparer And Filed/Stored Together With The Original Record.

3. The Data Must Be Checked For Accuracy By A Second Staff Member.

4. Investigate Why An Official Record Was Not Available At The Time. Implement Corrective Actions So That The Same Situation May Not Arise Again, E.G. Create A Form For The Record, Amend The Procedure, Change The Process So That The Record Is Captured Electronically Etc.

- Using True Copies

1. Sometimes There Is A Need To Use A Copy Of An Original Document Or Record, E.G. Attaching A Copy Of A Report To A Non-Conformance Record. So That It Is Apparent That The Record Is Not The Original:

2. Stamp Or Write On The Front Of The Copied Documentation, 'True Copy'.

3. Sign And Date The 'True Copy' Amendment.

- Modifying Records In A Compliant Manner

The Company GDP Procedure Should Stipulate How Data Or Entries May Be Amended. This Should Include Details On:

1. Any Standard Abbreviations Used, E.G. 'Not Applicable' (NA Or N/A) Etc.

2. Unacceptable Practices, E.G. Using 'Ditto' Marks (") To Indicate The Same Entry As Above, Leaving Empty Fields In A Form, Etc.

3. Who Is Responsible For Checking Documentation Amendments Or General GMP Compliance Of Logbook Pages Over Time.

\section{Conclusion}

Implementation Of A Good Documentation Practice For Pharmaceutical Products Will Facilitate Compliance With GMP And Regulatory Bodies. The Central Goal Of A GDP Is To Define The Manufacturers System Of Information \& Control, To Minimize The Risk Of Misinterpretation \& Errors Inherent In Oral Or 
Casually Written Communication, To Provide Unambiguous Procedures To Be Followed To Provide Confirmation Of Performance, To Allow Calculations To Be Checked \& To Allow Tracing Of Batch History And Also Ensure Quality Of Products. Pharmaceutical Manufacture And Regulation Is Clearly An International Business. With The Increasing Emphasis On Harmonization Efforts And Standard Setting, As Well As Mutual Recognition Agreements, Knowledge Of Foreign Regulations Is A Must Both For Understanding The Future Direction Of These Efforts As Well As For International Supply Of Drug Products. It Is Anticipated That The Approach Described Here Will Be A Useful Reference Work For Those Personnel Preparing And Using Documents For Pharmaceutical Manufacture. It Can Serve As A Tool For Training Staff And May Prove To Be Useful For Quality Assurance Professionals For Assessment Of Compliance During Self-Inspection. It Is Again Emphasized That Documentation Is A Very Important Aspect Of GMP And Will Enhance The Visibility Of The Quality Assurance Function.

[1] WHO Module 12 Part-2 January 2006

\section{References}

[2] Quality Assurance Of Pharmaceuticals. A Compendium Of Guidelines And Related Materials; 'Good Manufacturing Practices And Inspection'. Updated Edition. Vol 2. Geneva: World Health Organization; 2004. Pp. 58-85. Available From: Http://Whqlibdoc.Who.Int/Publications/2004/9241546190.Pdf Part I - WHO Good Manufacturing Practices: Main Principles For Pharmaceutical Products Http://Whqlibdoc.Who.Int/Publications/2004/9241546190 Part1. Pdf Part II - WHO Good Manufacturing Practices: Starting Materials Http://Whqlibdoc.Who.Int/Publications/2004/9241546190_Part2.Pdf [Last Cited On 2010 Feb 1]

[3] 8. Schedule M Good Manufacturing Practices And Requirements Of Premises, Plant And Equipment For Pharmaceutical Products; The Drugs And Cosmetics Act And Rules The Drugs And Cosmetics Act, 1940, (As Amended Up To The 30th June, 2005) And The Drugs And Cosmetics Rules, 1945; (As Amended Up To The 30th June, 2005) Available From: Http://Www.Cdsco.Nic.In/Html/Drugsandcosmeticact.Pdf [Last Cited On 2007 Jan 27]

[4] Guidance For Industry: Manufacturing, Processing Or Holding Active Pharmaceutical Ingredient, Draft Guidance; USFDA, Centre For Drug Evaluation And Research CDER March 1998

[5] White Paper, The 10 Golden Rules Of GMP; Pharmout Pty Ltd Www.Pharmout.Com.Au Version-01, 2008. Available From: Http://Www.Pharmout.Com.Au/Downloads/White Paper 10 Golden Rules.Pdf [Last Cited On 2010 May 6]

[6] Documentation And Records: Website Of GMP Online Consultancy. Available From: Http://Www.Gmp-OnlineConsultancy.Com/Gmp/Documentation-Records.Htm Accessed: [Last Cited On 2010 May 8]

[7] Documentation Requirement; Website Of GMP Quality. Available From: Http:/Www.Gmp-Quality.Com/Documentation.Html [Last Cited On 2010 May 8]

[8] Manohar A Potdar 'Pharmaceutical Quality Assurance' Nirali Prakashan.

[9] Www.Fda.Gov 